sub-standard projectors; thousands of film exhibitions are given annually with the same freedom as lantern lectures ; and many lantern slides, too, are now made on 'non-flam' base, which is both lighter and less fragile than glass. For Kodak negatives the 'non-flam' film has practically driven out the earlier bases, some of which were dangerously inflammable. No accident from a public exhibition of 'non-flam' film has ever been reported : a solitary mishap at Dulwich College was shown to have resulted from the inadvertent issue of an inflammable film from a Government department. The Post Office has now its own film factory and issues 'non-flam' films for public use. The Board of Education allows large sums to be spent to install 'sub-standard' projectors for open use in schools.

The Cinematograph Act, however, did not define an 'inflammable' film; and the Home Office, after leaving sub-standard projectors, with their 'acetate'-base films, unmolested for nearly twentyfive years, has now admitted, under question, that it is intended to "adapt the regulations to present conditions" and that "one of the points to be dealt with is the relaxation, in favour of slowburning films, of certain requirements necessary for fast-burning films". The implication here is that all films are "inflammable" within the terms of the Cinematograph Act, and that unless and until the Home Office "relaxes" its regulations, any film exhibition is liable to be regarded as a breach of the Act, unless it takes place under the very stringent regulations proper for 'standard' size films on 'nitrate' base.

It is difficult at first sight to believe that there is anyone who wishes to restrict the free use of sub-standard projectors or the general employment of films in private, in education and research, or in places of entertainment other than those larger halls where 'standard' projectors, and (consequently) inflammable films are still indispensable. But the premature glee with which certain newspapers have proclaimed the end of the 'non-flam myth' seems to betray such a desire; and it is obvious that if people can see the kinds of films they desire, co-operatively, safely and at small cost, without 'going to the pictures', it is not very good for interests which at one time had almost a monopoly of the cinema; as professional photographers monopolised photographs and lantern-slides before the days of the Kodak.

It is especially unfortunate, also, that this outcry about 'non-flam' films should have been confused in some minds with the quite different question whether private, social and educational exhibitions should be 'censored' or otherwise controlled in the supposed interests of morality, political orthodoxy, or what are popularly described as 'box-office' considerations. For, whereas 'non-flam' films and sub-standard projectors have until now been free from official interference on the ground of public safety, most authorities responsible for licensing halls for the exhibition of 'standard' and therefore 'inflammable' films, though legally concerned only with the personal safety of audiences, have in fact agreed to permit in their areas only films 'approved' by the British Board of Film Censors, a body which was set up by the film trade itself, shortly after the Cinematograph Act was passed.

This confusion of public safety with public morality has been the weakest point in British film administration throughout. If the public needs protection against improper or subversive films, it would seem reasonable that this should be assured under the laws regulating improper or subversive behaviour in general. If a censorship should be deemed unavoidable, let us have an official censor, responsible to one of the Secretaries of State, not to the 'trade', which has an interest in the matter, and not always a British interest.

Further, if "for securing safety" the Home Office wishes to "adapt the regulations to present conditions", it can make sub-standard projectors as safe and foolproof as their recognised public utility demands, simply by making it an offence, under the Cinematograph Act or otherwise, to manufacture or offer for sale films on 'nitrate'base of any width less than the standard $35 \mathrm{~mm}$. size. Any restriction or discouragement of the present general use of the sub-standard projector would be a disaster in public education, and also in the many branches of scientific research and teaching in which this valuable piece of apparatus is employed.

\section{The National Institute of Sciences of India} FURTHER details of the Indian Institute of Sciences, to which brief reference was made in NATURE of January 12 (p. 59), are now available. Elsewhere in this issue (p. 441) we print an article summarising the circumstances of its inception and recording the proceedings of the inaugural meeting. The desirability of having in India a national academy has long 
been felt, and this found expression a year ago in the appointment by the Indian Science Congress of a strong committee to elaborate a scheme for the establishment of an All-India Academy. It was feared by many that the work of this committee might have been jeopardised by the registration last June of an 'Indian Academy of Science' by Sir C. V. Raman in Bangalore. There were thus three bodies of 'academy' standing in India, the premier society-the Asiatic Society of Bengal-the United Provinces Academy of Science, and the new Indian Academy of Science. Fortunately, the common sense which has always been such a marked feature in the organisation of the Indian Science Congress, has enabled its committee to surmount all apparent difficulties and to secure the adherence of the officials of these three societies to the new Institute.

The Institute, with its headquarters in Calcutta, has received the support of all the most prominent men of science in India; it has started with one hundred foundation fellows, and in the future not more than ten will be elected annually. The fellowship will obviously, therefore, be a much prized distinction and since it is intended later to apply for a Royal Charter, the Institute will in effect become a Royal Society of India. It is not proposed that the Institute should publish a journal; publication will remain as one of the functions of the co-operating academies, which it is anticipated will be increased by the formation of academies in Bombay and in the Punjab. It will, however, issue a Proceedings summarising the papers read before these societies, and it will be prepared to assist them in the publication of expensive memoirs. An annual report, reviewing the progress of science in India, will also be issued, thus reviving on a broader basis that prepared formerly by the now defunct Board of Scientific Advice. The Institute proposes also to organise symposia on subjects of general and scientific interest. A further activity, on which emphasis is laid in the presidential address, will be "to promote and maintain a liaison between men of science and men of letters". Whilst a National Institute of Arts and Letters has still to be formed, the desired liaison has been effected in an indirect manner by the fact that one of the co-operating academies, the Asiatic Society of Bengal, is both an academy of science and of letters.

Of far greater importance, however, in our opinion, are two other functions referred to by Dr. Fermor : $(a)$ to appoint committees to which the Government and other bodies can apply for advice, and $(b)$ to secure and manage funds and endowments for scientific research. We advocated recently (NATURE, 134, 789; 1934) the formation in India of a National Research Council, and these two functions, if fully exploited, will in effect make the Institute such a Council. We understand that the Government of India has allocated a grant of 12,000 rupees $(£ 900)$ per annum to the Institute, and we do not doubt that further funds, from both public and private resources, will be placed at its disposal.

The formation of the National Institute is the most important development in the organisation of scientific activities in India which has occurred since the foundation in 1913 of the Indian Science Congress. It is but fitting that the Institute should owe its inception to this body.

\section{Reviews}

Embryology-Biological, Philosophical and

\section{Theological}

A History of Embryology. By Dr. Joseph Needham. Pp. xviii $+274+16$ plates. (Cambridge: At the University Press, 1934.) 15s. net.

Lov OVERS of Tristram Shandy will remember that passage in which Sterne gives a cut of his ironic whip at the learned Catholic doctors of the Sorbonne, who in their zeal to save souls had given a very precise account of the principles governing the baptism of unborn children, not forgetting detailed practical instructions for achieving it "avec une petite canule sans faire aucun tort à la mère". The Anglican divine suggested a more embracing method, "of baptizing all the homunculi slap-dash" beforehand, which he assures his readers could be done "avec une petite canule sans faire aucun tort au père".

We have here a very good example of the interweaving of theological and biological embryology. The homunculi are of course the spermatozoa, in the head of which, certain early microscopists had averred, miniature men had their habitation, ready to expand their preformed anatomy in the nutritive soil provided by the female. Some had insisted that they had actually observed the manikins, others had achieved the almost greater feat of asserting their existence on grounds of logical necessity. (Was it not the great Bonnet, 